The University of Maine

DigitalCommons@UMaine

Publications

Senator George J. Mitchell Center for Sustainability

Solutions

$10-2012$

\title{
Giving Voice to the Future in Sustainability: Retrospective Assessment to Learn Prospective Stakeholder Engagement
}

Mark W. Anderson

University of Maine - Main, mark.anderson@umit.maine.edu

mario f. teisl

University of Maine-Main, teisl@maine.edu

Caroline L. Noblet

University of Maine, caroline.noblet@maine.edu

Follow this and additional works at: https://digitalcommons.library.umaine.edu/ mitchellcenter_pubs

Part of the Economics Commons, and the Public Affairs, Public Policy and Public Administration Commons

\section{Repository Citation}

Anderson, M.W., Teisl, M.F., \& Noblet, C. L. 2012. Giving Voice to the Future in Sustainability: Retrospective Assessment to Learn Prospective Stakeholder Engagement. Ecological Economics 84, 1-6.

This Article is brought to you for free and open access by DigitalCommons@UMaine. It has been accepted for inclusion in Publications by an authorized administrator of DigitalCommons@UMaine. For more information, please contact um.library.technical.services@maine.edu. 
Unedited Draft - Not for Citation

Forthcoming in Ecological Economics

Giving Voice to the Future in Sustainability: Retrospective Assessment to Learn Prospective Stakeholder Engagement

Mark W. Anderson (corresponding author), Mario Teisl, and Caroline Noblet all of

School of Economics

The University of Maine

5782 Winlsow Hall

Orono, Maine 04469-5782

Email: mark.anderson@umit.maine.edu

Phone: 2075813198 
Unedited Draft - Not for Citation

Forthcoming in Ecological Economics

\section{Introduction}

Use of the word sustainability exploded in academic, commercial, and public discourse in the first decade of the $21^{\text {st }}$ Century. Despite numerous attempts to define the concept there is little consensus about the operational characteristics of the idea. Little progress was made in moving beyond the Brundtland Commission construct (WCED, 1987) that sustainability "meets the needs of the present without compromising the ability of future generations to meet their own needs”, a construct which “.... means so many different things to so many different people” (Robinson, 2004, p.373) and “embodies deep conceptual ambiguities” (Norton and Toman 1997, p. 553). Despite this lack of agreement on what sustainability means, at least two principles generate broad support.

First, sustainability is about fairness across generations, intergenerational equity. Robinson (2004, p.378), expressed it simply “....sustainability is predicated on a need to think across temporal scales." Norton (2005, p. 304) was even more forceful. "Sustainability is about the future, our concern toward it and our acceptance of responsibility for our actions that affect future people... [it] has to do with our intertemporal moral relations.” The patterns of resource use, savings, investment, and conservation in one generation clearly affect the opportunities available to future generations (Page, 1997; Padilla 2002; Kates and Paris 2003; UNDP 2011; Norton 2011). This is part of the bargain between generations captured in UNESCO’s (1997) Declaration on the Responsibilities of the Present Generation Toward Future Generations. Characterizing these obligations is where the definitional challenge comes. Norton and Toman (1997, p. 560) expressed this challenge: "If sustainability means anything...it represents a concern for the future, especially including horizons beyond the length of a human generation. 
Unedited Draft - Not for Citation

Forthcoming in Ecological Economics

...No discipline - not ecology, not economics, and not philosophy - provides a coherent and complete understanding of human values as they are applied across multiple generations.”

Second, sustainability is anthropocentric, it entails fealty to the needs, if not wants, of humans, usually interpreted as individual humans. While people's needs might include intrinsic values of nature, sustainability concepts are not biocentric. The importance attached to human needs is reflected in the growing sustainability science literature which emphasizes stakeholder engagement in the co-production of knowledge to accomplish sustainability (Cash et al., 2003; van Kerkoff \& Lebel, 2006). That is, people’s needs and the means of providing for these are not determined by sustainability researchers alone, but are the result of processes that include stakeholders in defining problems, co-operating in research, and co-interpreting findings. Norton (2005, p. 335-336) says the definition of sustainability “...must ultimately be a political question, to be determined in political arenas. The best way to achieve consensus in such arenas is to involve real communities in an articulation of values, in a search for common management goals...” From these values derive the needs people express, both in the present and the future.

We assert the largest groups of stakeholders for sustainability sciences are future generations. "The consequences of actions taken or not taken in an effort to live sustainably will fall most heavily on those who live in the future...” (Norton, 2005, p. 277) The question then is how can future interests be represented in decisions today that affect sustainability? Bromley (1998, p. 234) reflected on the difficulty inherent in this issue when he said, “...the essential problem of sustainability arises from the absence of knowledge about what those in the future would wish for us to do.... Those of us living today stand as dictators over the future and our analytical problem is that we are seeking to solve a provisioning problems for infinitely many individuals in the future, whose desires are entirely unknown and unknowable to us.” 
Unedited Draft - Not for Citation

Forthcoming in Ecological Economics

As difficult as it is to know and balance the diverse needs of the present generation (the intragenerational equity and efficiency problems), reference to the needs of the future seems nearly impossible. How can those in the present generation find means of speaking for or otherwise representing those future interests? How can present stakeholders know if their needs are in conflict with those of the future? Asking these questions is not to imply that the future has some right to control present decisions; rather it means that representing interests of the future in current decisions is necessary if we are to take sustainability seriously. Using the language of sustainability science, those who populate the future should be recognized as stakeholders in decisions made in the present. If those in the present are to be judged as good stewards by those in the future (Ball, 2001), those in the future need a "seat at the Table" (Norton, 2005) when deciding what are to be the objects of our stewardship.

To address the challenge of giving a voice to the future requires an understanding of the evolution of the sustainability concept. The importance of intergenerational bargains in these definitions should be understood, particularly as those bargains relate to the assertion, primarily from neo-classical economists, that the wants and needs of future humans are unknowable. This assertion is in contrast to the framework developed by Rawls (1971) to understand future interests in the concept of justice, an idea arguably similar to sustainability. There are both conceptual and practical difficulties inherent in thinking in a Rawlsian way; difficulties potentially addressed using a more pragmatic step, practicing future thinking retrospectively. We propose retrospective assessment as an approach to this way of thinking that draws on retrospective technology assessment (Tarr, 1976), historical analysis (Pesch and Garber, 2001), and backcasting (Robinson, et al., 2011), but is significantly different from each of these approaches. It is an approach consistent with multiple intellectual traditions, including the 
Unedited Draft - Not for Citation

Forthcoming in Ecological Economics

application of "historical social science" advocated by Wallerstein (2000) and inquiry into the dynamics of co-evolutionary processes (Waring, 2010).

Retrospective assessment is a tool that can be an effective pathway to prospective stakeholder engagement about the fundamental rules of a concept of sustainability. This then becomes a necessary precursor to finding a credible path toward addressing the basic intergenerational equity concerns inherent in sustainability.

2. Sustainability as intergenerational equity and the neo-classical economics challenge

The idea of sustainability has deep roots in the environmental movements of the $20^{\text {th }}$ Century and can be traced at least as far back as the debate in the U.S. over the Hetch Hetchy dam (Nash, 1982; Robinson, 2004), one of the first major public controversies over the environmental legacy owed to the future. This line of thinking about sustainability before the term was used can be traced to Leopold (Norton, 1988) to William Vogt (1948) and then to proponents of the limits to growth argument (Meadows et al., 1972).

Herman Daly (1980) proposed steady-state economics as a solution to problems identified in the limits to growth arguments. In developing the steady-state concept, Daly clearly recognized the problem as inherently one of intergenerational fairness, though without reference to the term sustainability. "In taking care of that [God's] creation, special, but not exclusive, attention must be given to humanity, including not only the present but also future generations ...” (Daly, 1980, p. 371).

Concurrent with Daly, Talbot Page (1977, p. 192) investigated materials policy and developed a theory of "permanent livability," that keeps "the resource base intact." Page argued, “....certain questions important to materials policy and environmental economics in general 
Unedited Draft - Not for Citation

Forthcoming in Ecological Economics

becomes remarkably difficult to conceptualize. Among these are: 'What are our obligations to the future?' 'What is intertemporal fairness or justice?' and 'When can we say that the future ‘regrets’ a decision made by the present?’” (p. 200).

These brief examples illustrate the breadth of understanding that sustainability recognizes limits, and entails intergenerational concern; culminating in 1987 with the final report of the World Commission on Environment and Development (WCED), the so-called Brundtland Report, which adopts the term Sustainable Development.

The WCED (1987) report dealt with the complexities of both the distribution and quality of growth, reflecting both intragenerational and intergenerational tradeoffs. The prominence of the report and its findings meant sustainable development became the preferred term for capturing the idea that intergenerational issues are at the heart of resource and environmental problems. Despite critics like Daly (1993), sustainable development gained acceptance as a term to express concern about a multitude of social and environmental issues.

In the midst of this explosion of use of the sustainability idea, the academic literature also experienced its own explosion. Some literature attempted to develop the idea of sustainability beyond the Brundtland Report definition, which had little operational applicability. How would we know if a society were moving toward sustainability or not? Since economics has a history of asserting a means for approaching the tradeoffs among various resource allocations over time, it is not surprising that sustainability became a focal point for some economics sub-disciplines, particularly resource and environmental economics (Pearce, 2002) and ecological economics (Costanza, 1991).

One proposal for addressing the intergenerational tradeoffs inherent in sustainability was a distinction between weak and strong sustainability (Hubacek and Mauerhofer, 2008, p. 414). 
Unedited Draft - Not for Citation

Forthcoming in Ecological Economics

Building on capital theory in the economics of growth, the distinction between weak and strong sustainability focused on questions of how fungible are various forms of capital - natural, artificial, human and social. To leave the future able to meet its own needs implies the present generation leaves the future with a sufficient endowment of capital.

In the weak sustainability construct, capital is assumed to be largely fungible with broad opportunities for substitution among capital types. In this view, the obligation to the future is to leave it an undiminished aggregate capital stock. Society could compensate for the depreciation in one capital stock with investments in another; e.g., a decline in natural capital could be offset by increases in human or artificial capital. The problem of sustainability then is one of finding a savings rate in the present large enough to invest in capital formation to offset the exploitation of natural capital and depreciation of artificial and human capital (Solow, 2000).

Strong sustainability proponents questioned the assumption of capital substitution, particularly when it comes to the decline in natural capital (Norton, 2005, Chapter 8). They argued sustainability requires the present generation leave the future an undiminished stock of natural capital. In broad terms, this requires renewable resources be exploited at less than their maximum sustainable yield, and non-renewable resources (fossil fuels, for example) be exploited only when they are replaced with investments in renewable resource capital stock to offset the loss of non-renewable capital. Norton (2005, p. 320) goes further to describe strong ecological sustainability: "There are some elements or processes in nature that are so important to the future that no generation is permitted to destroy them. ...If these resources are lost, future people will be worse off than they would have been had the items been protected - even if they are more wealthy than their ancestors." (emphasis original). This one debate over the nature of sustainability shows the importance of intergenerational effects to a meaningful operational 
Unedited Draft - Not for Citation

Forthcoming in Ecological Economics

definition of the term. Instead of only addressing the question -- what does it mean to meet the needs of the future -- we must also ask -- how do we know what resources are “...so important that no generation is permitted to destroy them?"

Neoclassical economists questioned whether there was an operational definition of sustainability, best represented by Solow. While acknowledging that sustainability “...says something about a moral obligation that we are supposed to have for future generations," he concluded that “...sustainability is an essentially vague concept” (2000, p. 180) because “... the preferences, of future generations are something that we don’t know about” (2000, p. 181). Solow made clear there is a relationship between the present and the future when "... thinking about sustainability as a matter of distributional equity between the present and the future, you can see that it becomes a problem about saving and investment” (p. 183).

The questions of whose preferences matter and how they are counted and balanced are at the heart of the differences between sustainability advocates and conventional economists whose approach to resource allocation over time includes benefit-cost analysis. Conventional application of benefit-cost analysis (BCA) in neoclassical welfare economics assumes current preferences are valid bases for valuing benefits and costs into the future (Just, Heuth, \& Schmitz, 1982). BCA assumes the current distributions of income, resources, and power are a legitimate foundation for the analysis, either because the analysis is deemed to focus only on efficiency rather than equity concerns or because the marginal utility of income is homogeneous across individuals, present and future. Further, it assumes that it is appropriate to use a social discount rate to discount future benefits and costs and calculate a "present value of net benefits".

Critics of BCA question all of these assumptions. Hubacek and Mauerhofer (2008, pp. 415-416) provided a brief summary of these critiques; and Padilla (2002) specifically critiqued 
Unedited Draft - Not for Citation

Forthcoming in Ecological Economics

the intergenerational assumptions of the neoclassical welfare framework. Norgaard and Howarth (1991) showed the "conservationist's dilemma" in the application of higher and lower discount rates and their intergeneration effects. Ball (2001, pp. 106-107) shows that even applying “individualist principles,” social discounting is ethically questionable. Norton et al. (1998, p. 209) show that changes in preferences are both possible and just as important as changes in prices “...to achieve our long-term social goals.” Rawls (1971, pp. 22-27) outlined the flaws in utilitarianism which underlie conventional economic models. In sum, the neo-classical benefit cost approach violates the intergenerational equity condition at the heart of sustainability.

Here, we wish to address whether we can know future preferences. Clearly, if Solow is right and we cannot know what the future would prefer, there is no means to operationalize sustainable development without assuming that preferences are unchanging. If so, then present preferences represent proxy votes for future generations. However, experience tells us that preferences change over time both individually and collectively.

3. How can we know about the future?

John Rawls (1971), in his Theory of Justice, provided one framework for thinking about our obligations to the future and how such reflection might shape our vision of sustainability science today. Rawls was interested in understanding what the fundamental rules might be for establishing a just society, rules that would determine the distribution of "primary goods." Justice is a concept, like sustainability, which inherently deals with intergenerational issues. The process Rawls advocated for establishing general rules for justice are potentially applicable for establishing principles of sustainability, particularly the rules of fairness acceptable to both the present and future. Indeed the UN Development Program (2011, p. 1) makes explicit the 
Unedited Draft - Not for Citation

Forthcoming in Ecological Economics

similarity “...the intersections between environmental sustainability and equity, which are fundamentally similar in their concern for distributive justice.”

To simplify, Rawls proposed using social contract theory to imagine people in an “original position” who would be charged with setting the broad rules for a just society. The participants would be empanelled behind a "veil of ignorance," ignorant of their class, social status, fortune, abilities, and, importantly for our purposes, "which generation they belong." The advantage of this so-called "original position" is that, "No one knows his situation in society nor his natural assets, and therefore no one is in a position to tailor principles to his advantage” (Rawls, 1971, p. 139).

Talbot Page (1977) applied the Rawlsian approach to resolve the inherent conflict he saw between different approaches to the allocation of resources over time. He created a framework for reconciling the "present value criterion" which emphasizes efficiency and the "conservation criterion" which favors "permanent livability," a term roughly equivalent to sustainability, a term not yet in vogue when Page developed this idea. Page (1977, p. 203) said that "One of the important ideas of the original position is that it links all generations together in a common perspective.” From this perspective, Page proposed a two-tiered process whose results would yield adoption of the conservation criteria by those in the original position to assure that “...each generation should be intertemporally self-sufficient” and then apply “...the market version of the present value criterion, the efficiency criterion..." for short-run decisions about resource allocation (pp. 203-204).

Norton (1989) used Page's application of Rawls to argue in more detail what preferences would be expressed in the original position among competing viewpoints on resource allocation. He argued that the Rawlsian approach represents “.... neutral and adequate vocabulary for 
Unedited Draft - Not for Citation

Forthcoming in Ecological Economics

environmental decision-making” (p.152). Such an approach would lead to “...a society in which each generation acts on a broadly naturalist-preservationist approach to time preference” (p. 155).

Despite the efforts of Page, Norton, and others to use a Rawlsian approach for thinking about what future generations might expect in terms of sustainability, there are several conceptual and practical challenges to applying Rawls in this way. Even accepting that the problem of defining the conditions of sustainability is analogous to that of defining justice, there is not a clear path to using Rawls' framework for several reasons.

One basic problem is that future generations are constituted of non-existent beings (Hubin, 1976, p. 71). The obvious question is can we have an obligation or duty to beings that do not yet exist? Even if we answer in the affirmative, clearly our relations with future generations are asymmetrical. Ball (2001, p. 95) summaries this assertion, "The reciprocity theory of rights holds that we have duties only toward those who are in a position to reciprocate by respecting our rights."

Rawls had anticipated this issue in his initial description of the "original position" by suggesting a contract where participants are ignorant of which generation they are part of (p. 137). Then he modified the description of the original position and adopted a "present time of entry" interpretation. In this variant of the original position, contractors know that those in the original position are all of the same generation, but they do not know which generation this is. That interpretation still causes difficulties for our purposes here. As Hubin (1976) argued, even with the present time of entry interpretation “...it is not clear that we can construct principles of justice (sustainability also?) which apply to all societies at all levels of development without making them either trivial or too complex to be manageable” (p. 80). 
Unedited Draft - Not for Citation

Forthcoming in Ecological Economics

The question of whether the contractors in the original position should be ignorant of their generation or whether one should adopt the "present time of entry interpretations" speaks to the fundamental challenge of using a Rawlsian approach to address the issue of future generations of humans as stakeholders in sustainability science. As English (1977) said, "Rawls' original position is not described as a historical event...The original position is supposed to be a point of view or basis for moral reasoning which anyone can adopt at any point in time” (p. 98). Rawls was interesting in developing a method for deducing the principles of justice to be applied to the allocation of primary goods. Our question is in a sense much more pragmatic in its ends. While the Rawls a priori approach is amenable to trained philosophers, it is probably not practical in this context where the goal is to have those in the present think concretely about how future stakeholders would wish us to behave with respect to them.

Furthermore, notwithstanding the claims of Page and Norton, many people balk at the idea that we could effectively place ourselves behind a Rawlsian "veil of ignorance.” While it is possible to imagine not knowing one's gender, class, income, capabilities, or generation it is much more difficult to assert with confidence how one would decide about the rules of intergenerational allocations under such ignorance. We do know our status and most people understand that such knowledge colors their judgments about things like the rules of intergenerational resource use. It is hard to adopt the veil of ignorance when we know our individual status. So while Rawls inspires us to think about how future stakeholders might evaluate our decisions today, a more pragmatic method of accomplishing this is necessary.

4. Futures Research as a learning system for intergenerational fairness 
Unedited Draft - Not for Citation

Forthcoming in Ecological Economics

Are there models applicable to sustainability science that could be used as a pragmatic alternative to a Rawlsian framework? How might we consider of preferences of future generations to think more rigorously about the concept of sustainability?

The tradition of futures research provides a potential system for thinking about how the people of the future would respond to the bequest package we leave for them. The prospect of knowing about the future, not just the preferences of those in the future, was clear to the pioneers of futures research (Gordon, 1977). Researchers developed techniques of conjecture (de Jouvenel, 1967), imagining (Polak, 1973), and scenario building (Boucher, 1977) as approaches to developing such an understanding. Two specific techniques offer concrete examples of the approach we advocate here.

First are the techniques of technology assessment. Technology assessment was one of the early tools developed within futures research movement (OECD, 1967; Anderson, 1975). The basic premise was that interdisciplinary studies of emerging technologies could identify potential social, economic, environmental, or other problems before the technologies were widely adopted. Retrospective technology assessment (RTA) was a methodology proposed to improve the technique of technology assessment (Tarr, 1976; Coates, et al., 1982). The idea of RTA was that you could learn how better to think about the future by thinking about the past. Specifically, one means to develop better techniques for technology assessment would be to do an assessment on a fully developed technology using only the information available before the technology was adopted by society. This would allow researchers to judge whether the technique could have identified the impacts of the technology as it eventually developed. One obvious problem of this research is the moral hazard issue of being sure you only used the information available before the technology was adopted. Could you do RTA while maintaining 
Unedited Draft - Not for Citation

Forthcoming in Ecological Economics

"ignorance" about what actually happened? This is a similar problem to that inherent in

Rawlsian thinking.

A much more recent technique, and one applied explicitly to sustainability, is backcasting (Fischer et al, 2007; Robinson et al, 2011). "Backcasting works through envisioning and analyzing sustainable futures, and subsequently by developing agendas, strategies, and pathways how to get there” (Vergragt and Quist, 2011, p. 747). Much like scenario development of an earlier era (Boucher, 1977,), backcasting is inherently a normative exercise, constructing visions of desirable futures and then working backwards to identify the means of achieving those futures. Even when it engages stakeholders in participatory processes, backcasting still relies on the preferences of the present to construct desirable futures, so it assumes that preferences will remain unchanged in the future. In that sense, it fails to meet the desirability for a "neutral and adequate vocabulary” that Norton ascribes to a Rawlsian approach to intergenerational equity. What RTA and backcasting offer are models for how to use thinking about the past to learn how to better think like or on behalf of the future (Heilbroner, 1960). Since we cannot engage the future directly as stakeholders and, as we observe above, it is hard to imagine reliably extracting ourselves from our present biases to think in a Rawlsian original position, we need to learn new ways to think intergenerationally as an intermediate step. The reflective equilibrium Rawls (1971, pp. 48-51) advocates for might be started by thinking retrospectively.

5. Retrospective assessment as a learning system for prospective stakeholder engagement In broad terms there are three categories of the bequest package from one generation to the next. Decisions in the present will be perceived in the future with indifference, regret, or gratitude. The concept of sustainability suggests that rules about what the current generation 
Unedited Draft - Not for Citation

Forthcoming in Ecological Economics

leaves as a legacy should generate gratitude or indifference and minimize regrets from the future, while satisfying the needs of the current generation. How can we best judge the likely effects the implicit social rules about current resource, environmental, economic, and social decisions have on the future? The first step in this process is to practice retrospective assessment, not as an end in itself but as a means of understanding how our stewardship, or lack of it, might be perceived by those in the future.

The idea of retrospective assessment is to ask people to think about the bequests of previous generations in the same terms - indifference, regret, and gratitude. In the language of sustainability science (Kates et al., 2001; Cash et al., 2003; van Kerkoff and Lebel, 2006), the task is for people to consider themselves as present stakeholders evaluating decisions made in the past. This is alien thinking for many in modern society. We enjoin no need to "cry over spilled milk" and past decisions are "water over the dam" or "water under the bridge.” This forward only perspective is even formally enshrined in BCA where "sunk costs are irrelevant." The alternative, retrospective thinking, starts us down the road to learning how to evaluate future reactions to the legacy we leave.

Despite the promise that retrospective assessment may hold for evaluating decision making, the social psychology literature identifies some cognitive barriers that may limit the effectiveness of this technique including bounded rationality, willpower and self-interest. These barriers need to be understood in the construct of any approach to using retrospective assessment as we propose here.

The literature indicates that individuals have limited cognitive abilities, even when evaluating, or knowing their own current preferences (Rabin, 1998). An additional challenge for evaluating decisions is that humans use heuristics to simplify decision making given that internal 
Unedited Draft - Not for Citation

Forthcoming in Ecological Economics

mental resources are scarce (Frey and Stutzer, 2007; De Dreu and Steinel, 2006; Zwick, Erev and Budescu, 1999). Present well-being may not be entirely dependent upon outcome (substantive rationality) either, but rather the process by which the outcome was achieved (procedural rationality); thus for many people the process leading to our current state is just as important as the state itself (Frey, 2007; Messick, 2006; Chess and Purcell, 1999). Given retrospective evaluation asks individuals to consider their current state, this line of inquiry may also encounter status quo bias (Jost, Banaji and Nosek, 2004). There may also be a prevailing perception among individuals that the decisions which yielded the current state were superior over other alternatives (i.e., a form of system justification bias (see Moshinsky and Bar-Hillel, 2010). While bounded rationality may limit the ability of individuals to make ideal decisions, we wonder if retrospective assessment offers a means of incorporating these limitations into future decision making. By providing an opportunity to think through future decision making through the lens of the past we may avoid the use of heuristics or other biases.

Individuals may also experience bounded willpower, where choices are made in the immediate time period that are not beneficial in the long run, including overestimating one’s own ability to change behavior in the future -particularly with respect to self-control (Rabin, 1998; Dellavigna, 2009; Sent, 2004). In short, evidence suggests people discount and mispredict the utility of the future including projecting their own current preferences onto future periods (Frey and Stutzer, 2007; Dellavigna, 2009; Rabin, 1998). Retrospective assessment may allow for partial removal of risk-taking and discounting behavior often associated with forward looking decisions. Creating a concrete scenario of how previous decisions impacted the current generation, we hypothesis individuals may exercise more caution, and less discounting, in their future decision making. 
Unedited Draft - Not for Citation

Forthcoming in Ecological Economics

Finally, evidence reminds us that humans are social beings who may make decisions at a social level. Thus, bounded self-interest leads individuals to sacrifice to their own interest to help others, acting more as a social unit than an individual perhaps because for some individuals their utility function depends on the payoffs to others (Sent, 2004; Dellavigna, 2009).

Retrospective assessment may provide a context within which individuals consider the impacts of decision not only on themselves, but on society as a whole.

Keeping these potential barriers in mind, retrospective assessment is a path toward building legitimacy (Cash et al., 2003) for current decisions among what we believe to be the largest group of sustainability science stakeholders. Reflecting on what about previous decisions contributed to or detracted from sustainability is a concrete exercise in intergenerational thinking. It should make current humans more aware of potential implications of current actions on the future. Norton (2005) argued for democratic processes to uncover community values in sustainability. Reflective consideration of past decisions is a practical way of thinking about community values as concrete manifestations of reactions to the past. Only by reflection on our role in the present as stakeholders in past decisions can we hope to think more clearly about the future as stakeholders in current decisions.

Retrospective assessment can also be applied to BCA. That is, economic researchers could begin to re-examine previously performed BCAs to learn if the assumptions made about the world had passed the test of time. Did changes in technologies, resources or values alter the evaluation of the final outcome? Building a literature in retrospective BCA could lead to improvements in the design of future BCAs. For example, examining a number of past analyses may indicate that some assumptions are more robust than others, show where sensitivity analysis is needed, and suggest alternative assumptions or procedures. Retropective BCAs may provide 
Unedited Draft - Not for Citation

Forthcoming in Ecological Economics

better understanding how to include the precautionary principle in future BCAs, and it could train researchers to think differently about how BCAs should be framed, thus improving how future BCAs are done.

But these and other related questions are unambiguously difficult to answer because we have little experience trying to imagine how the future thinks (Polak, 1973). We need to practice within a new learning system and the best way to do this is to capitalize on our experience as stakeholders in decisions made by those in the past. We are literally the future stakeholders in past decisions. So, retrospective assessment is a central element of a social learning system (Schon, 1971) to do meaningful prospective assessment.

This general approach of retrospective assessment to help learn how the future would participate in the intergenerational allocation of resources is historic (Wallerstein, 2000), pragmatic (Norton, 2005), and still in the liberal tradition in that “...acting justly (sustainably also?) toward our distant descendants requires that we refrain from acting in ways that will unduly limit their liberty or diminish their autonomy” (Ball, 2001, p. 103). For Ball this suggests a "practice of punctuated reciprocity” as the ethical basis for stewardship. “...(E)ach succeeding generation reciprocates what it had received from earlier generations, doing unto later generations what was (or at any rate should have been) done unto it” (pp. 103-104). Of course, the only way for such an approach to work is some sort of systematic evaluation of what was done or should have been done, retrospective assessment.

\section{Toward Praxis}

Asking current people to think about themselves as sustainability stakeholders in past decision is a logical step toward making future generations stakeholders in current decisions. It 
Unedited Draft - Not for Citation

Forthcoming in Ecological Economics

begins the process of giving the future a seat at the table. This makes concrete the idea of intergenerational bequest packages and by doing so allows people to think more concretely about how future humans will judge the decisions that we make now, our bequests to the future.

We propose a four-step process for a learning forum around the idea of engaging the future as stakeholders in sustainability. This process is analogous to the values clarification proposed by Norton (2005). These steps are as follows:

1. An individual exercise in retrospective regrets and gratitude using a broad cross section of community members as participants. In this, participants would be asked to think about previous societal decisions they regret, are grateful for, or are indifferent to.

2. Asking those individuals then to discuss their regrets and gratitude in small group settings to identify common elements of past decisions they feel each way about. This would help uncover the community values expressed in historical regret or gratitude in the pragmatic sense advocated by Norton.

3. Use these common elements in a survey of representative samples of the whole community to test where there might be consensus.

4. Reconvene the community groups to consider the survey data and then consider how this information helps people think in a prospective way about future reactions to current decisions. What of our actions will the future regret and what will it be thankful for?

We further suggest researchers begin retrospective BCAs with the aim of improving the quality of future BCAs; just as meta-analyses of valuation studies helps us in how we think about these studies. Building a literature in retrospective BCA may lead to new insights on what is 
Unedited Draft - Not for Citation

Forthcoming in Ecological Economics

most robust, and what is most uncertain, in performing BCAs. Indeed, the recommendations above may help bridge the divide between BCA and Rawlsian analysis.

Norton (2005, Chapter 7) suggests that adaptive management systems in a sustainability framework requires an iterative, community-based process considering values and metrics of sustainability as a commitment to democratic values. We propose this stepwise retrospective process as a means toward prospective thinking, a way of accomplishing Norton's commitment to democracy while including the future as part of the community whose values matter. This would be a logical next step in the evolution of ethics proposed by Aldo Leopold (1949) when he urged expanding the community of consideration: Leopold's land ethic "enlarges the boundaries of the community to include soils, waters, plants, and animals...” Our proposal expands the sense of community to include one more element - the people of the future.

Acknowledgements: This research was conducted as part of Maine’s Sustainability Solutions Initiative, supported by National Science Foundation award EPS-0904155 to Maine EPSCoR at the University of Maine. We are grateful for insightful comments on an earlier draft of this paper from David Vail, Roger J.H. King, Timothy Waring, and two anonymous reviewers.

\section{References}

Anderson, M.W. 1978. The institutionalization of futures research in the U.S. Congress. Technological Forecasting and Social Change. 11, 287-296.

Ball, T. 2001. New Ethics for Old? Or How (not) to Think About Future Generations. Environmental Politics, 10(1), 89-110. 
Unedited Draft - Not for Citation

Forthcoming in Ecological Economics

Boucher, W.I. (Ed.) 1977. The Study of the Future: An Agenda for Research. U.S.

Government Printing Office. Washington, D.C.

Bromley, D.W. 1998. Searching for sustainability: The poverty of spontaneous order.

Ecological Economics. 24, 231-240.

Cash, D.W. et al. 2003. Knowledge systems for sustainable development. PNAS. 100, 8086-

8091.Chess, C. \& Purcell, K. (1999). Public Participation and the Environment: Do

We Know What Works? Environmental Science and Technology, 33 (16), 2685-

2692.

Coates, V.T., Fabian, T. and McDonald, M. 1982. Nineteenth Century Technology-

Twentieth Century Problems: A Retrospective Mini-Assessment. EPA-600/S9-82--

011. Washington, D.C.: U.S. Environmental Protection Agency.

Costanza, R. 1991. Ecological Economics: The Science and Management of Sustainability.

Columbia University Press. New York.

Daly, H. 1980. Postscript: Some Common Misunderstandings and Further Issues Concerning a Steady-state economy. In Daly, H. (Ed.). Economics, Ecology Ethics: Essays Toward a Steady-State Economy. Freeman: San Francisco.

Daly, H. 1993. Sustainable Growth: An Impossibility Theorem. In: Daly, H. (Ed.). Valuing the Earth. MIT Press. Cambridge.

De Dreu, C.K.W. and Steinel, W. 2006. Social Decision Making in Fuzzy Situations: Motivated Information Processing and Strategic Choice, in Social Psychology and Economics (DeCremer, Zeelenberg and Murnighan eds). Lawrence Erlbaum Associates, Publishers. London. 
Unedited Draft - Not for Citation

Forthcoming in Ecological Economics

de Jouvenel, B. 1967. The Art of Conjecture. Basic Books. New York.DellaVigna, S. 2009.

Pscyhology and Economics: Evidence from the Field. Journal of Economic

Literature 47(2): 315-372.

English, J. 1977. Justice Between Generations. Philosophical Studies. 31(20), 91-104

Fischer, J., Manning, A. D., Steffen, W., Rose, D. B., Daniell, K., Felton A., Garnett, S.,

Gilna, B., Heinsohn, R., Lindenmayer, D. B., MacDonald, B., Mills, F., Newell,

Reid, B., J., Robin, L., Sherren, K., and Wade A. 2007. Mind the sustainability gap.

Trends in Ecology and Evolution, 22(12), 621-624.

Frey, B.B. and Stutzer, S. 2007. Economics and Psychology: Developments and Issues. in Economics and Psychology: A Promising New Cross-Disciplinary Field (Frey and Stutzer eds). MIT Press.

Gordon, T.J. 1977. The Nature of Unforeseen Development. In Boucher, W.I. ed. The Study of the Future: An Agenda for Research. U.S. Government Printing Office. Washington, D.C.

Heilbroner, R. 1960. The Future as History. Harper. New York.

Hubacek, K. and Mauerhofer, V. 2008. Future generations: Economic, legal and institutional aspects. Futures, 40, 413-423.

Hubin, D.D. 1971. Justice and Future Generations. Philosophy and Public Affairs. 6(1), 7083.Jost, J.T. and Banaji, M.R. and Nosek, B.A. (2004). A Decade of System Justification Theory: Accumulated Evidence of Conscious and Unconscious Bolstering of the Status Quo. Political Psychology, Vol. 25, No. 6, 2004

Just, R.E., Hueth, D.L., and Schmitz, A. Applied Welfare Economics and Public Policy. Prentice-Hall. Englewood Cliffs, N.J. 
Unedited Draft - Not for Citation

Forthcoming in Ecological Economics

Kates, R.W. et al. 2001. Sustainability science. Science. 292, 641-642.

Kates, R.W. and Parris, T.M. 2003. Long-term trends and a sustainability transition. PNAS. 100, 8062-8067.

Leopold, A. 1949. A Sand County Almanac and Sketches Here and There. Oxford University Press. New York.

Meadows, D.H., Meadows, D.L., Randers, J., and Behrens, W. 1972. The Limits to Growth. Universe Books. New York.

Messick, D.M. 2006. Utility and the Psychology of Preference. in Social Psychology and Economics (DeCremer, Zeelenberg and Murnighan eds). Lawrence Erlbaum Associates, Publishers. London.

Moshinsky and Bar-Hillel. 2010. Loss Aversion and Status Quo Label Bias. Social Cognition, Vol. 28, No. 2, 2010, pp. 191-204

Nash, R. F. 1982. Wilderness and the American Mind. ( $4^{\text {th }}$ ed.). Yale University Press. New Haven.

Norgaard, R.B. and Howarth, R.B. 1991. Sustainability and discounting the future. In. Costanza, R. ed. Ecological Economics: The Science and Management of Sustainability. Columbia University Press. New York.

Norton, B. 1988. The Constancy of Aldo Leopold's Land Ethic. Conservation Biology. 2, 93102.

Norton, B.1989. Intergenerational Equity and Environmental Decisions: A Model Using Rawls’ Veil of Ignorance. Ecological Economics. 1, 137-159.

Norton, B. 2005. Sustainability: A Philosophy of Adaptive Ecosystem Management. University of Chicago Press. Chicago. 
Unedited Draft - Not for Citation

Forthcoming in Ecological Economics

Norton, B. 2011. Intergenerational Equity. In Berkshire Encyclopedia of Sustainability. Vol.

3. The Law and Politics of Sustainability. Berkshire Publishing. Great Barrington, Massachusetts.

Norton, B. et al. 1998. The evolution of preferences: Why ‘sovereign’ preferences may not lead to sustainable policies and what to do about it. Ecological Economics. 24, 193211.

Norton, B. and Toman, M. 1997. Sustainability: Ecological and Economic Perspectives. Land Economics. 73, 553-568.

Organization for Economic Cooperation and Development (OECD). 1967. Technology Forecasting in Perspective. Paris.

Padilla, E. 2002. Intergenerational equity and sustainability. Ecological Economics. 41, 6983.

Page, T. 1977. Conservation and Economic Efficiency. Johns Hopkins University Press. Baltimore.

Page, T. 1997. On the problem of achieving efficiency and equity, intergenerationally. Land Economics. 73, 580-596.

Pearce, D. 2002. An Intellectual History of Environmental Economics. Annual Review of Energy and the Environment. 27, 57-81.

Pesch, C.E. and Garber, J. 2001. Historical Analysis, a Valuable Too in Community-based Environmental Protection. Marine Pollution Bulletin, 42(5), 339-349.

Polak, F. 1973. The Image of the Future. Boulding, E. (trans.) Elsevier. New York.

Rabin, M. 1998. Psychology and economics. Journal of Economic Literature, 36, 11-46.

Rawls, J. 1971. A Theory of Justice. Belknap Press. Cambridge. 
Unedited Draft - Not for Citation

Forthcoming in Ecological Economics

Robinson, J. 2004. Squaring the circle? Some thoughts on the idea of sustainable development. Ecological Economics. 48, 369-384.

Robinson, J. et al. 2011. Envisioning sustainability: Recent progress in the use of participatory backcasting approaches for sustainability research. Technological Forecasting and Social Change. 78, 756-768.

Schon, D. 1971. Beyond the Stable State. New York: WW Norton.

Sent, E.M. 2004. Behavioral economics: How psychology made its (limited) way back into economics. History of Political Economy, 36, 735-760.

Solow, R. M. (2000). Sustainability: An Economist’s Perspective. In. R.N. Stavins (Ed.), Economics of the Environment. WW Norton. New York.

Tarr, J.A. (1976). Retrospective Technology Assessment. Technology and Culture. 18, 655658.

UNDP. 2011. Sustainability and Equity: A Better Future for All. United Nations Development Program. New York.

UNESCO. 1997. Declaration on the Responsibility of the Present Generations Toward Future Generations. 29 C/Resolution 44. Paris.

van Kerkof, L. and. Lebel, L. (2006). Linking knowledge to action for sustainable development. Annual Review of Environment and Resources. 31, 445-477.

Vergragt, P.J. and Quist, J. 2011. Backcasting for sustainability: Introduction to the special issue. Technological Forecasting and Social Change. 78, 747-755.

Vogt, W. 1948. Road to Survival. William Sloane Associates. New York.

Wallerstein, I. 2000. Hold the Tiller Firm: On Method and the Unit of Analysis. In The Essential Wallerstein. The New Press. New York. 
Unedited Draft - Not for Citation

Forthcoming in Ecological Economics

Waring, T.M. 2001. New evolutionary foundations: Theoretical requirements for a science of sustainability. Ecological Economics. 69, 718-730.

World Commission on Environment and Development (WCED). 1987 Our Common Future. Oxford University Press. New York.

Zwick, R., Erev., I. and D. Budescu. 1999. The Psychology and Economical Perspectives on Human Decisions in Social and Interactive Contexts. In Budescu, Erev and Zwick (Eds.), Games and Human Behavior: Essays in honor of Amnon Rapoport. Lawrence Erlbaum Associates: New Jersey. 